\title{
Effect of kidney-reinforcing and marrow-beneficial Chinese medicine on bone metabolism-related factors following spinal cord injury in rats
}

\author{
DA-AN ZHOU ${ }^{1,2}$, YUE NING DENG ${ }^{1}$, LEI LIU ${ }^{1}$ and JIAN JUN LI ${ }^{2}$ \\ ${ }^{1}$ Department of Rehabilitation, The Third Affiliated Hospital of Jinzhou Medical University, Jinzhou, Liaoning 121000; \\ ${ }^{2}$ Department of Spinal and Neural Function Reconstruction, China Rehabilitation Center, Beijing 100086, P.R. China
}

Received February 3, 2015; Accepted January 15, 2016

DOI: $10.3892 /$ etm.2016.3304

\begin{abstract}
The present study aimed to investigate the effect of traditional Chinese kidney reinforcing and marrow-beneficial medicine (KRMB) on the prevention and treatment of abnormal bone metabolism and osteoporosis (OP) resulting from spinal cord injury (SCI). Rat models of OP following SCI were surgically established. The rats were randomly divided into five groups: Normal; sham operation + KRMB; normal + KRMB; $\mathrm{SCI}+\mathrm{KRMB}$; and SCI model group. Bone mineral density (BMD), and the expression of bone gamma-carboxyglutamic-acid containing protein (BGP), hepcidin mRNA and bone sialoprotein (BSP) were recorded at 1, 2, 4, 6, 8 and 10 weeks after the operation. BMD expression in the SCI model group was significantly lower compared with the normal, sham + KRMB and normal + KRMB groups at 4, 6, 8 and 10 weeks $(\mathrm{P}<0.01)$, and was significantly lower than that in the SCI + KRMB group at $6(\mathrm{P}<0.05), 8$ and 10 weeks $(\mathrm{P}<0.01)$. The level of serum BGP in the SCI model group was significantly higher compared with the normal, sham + KRMB and normal + KRMB groups at each time point $(\mathrm{P}<0.01)$, and lower than the $\mathrm{SCI}+\mathrm{KRMB}$ group $(\mathrm{P}<0.01)$. The $\mathrm{SCI}+\mathrm{KRMB}$ group was significantly higher than the normal, sham operation + KRMB and normal + KRMB groups $(\mathrm{P}<0.01)$. Hepcidin mRNA expression in the rat livers in the normal, sham + KRMB and normal + KRMB group was significantly higher than that in the SCI + KRMB group and SCI model group at each time point $(\mathrm{P}<0.01)$. Hepcidin mRNA expression in the SCI + KRMB group was significantly higher than that in the SCI model group at 1 week $(\mathrm{P}<0.01)$, and significantly higher than the SCI model group at 2, 4, 6 ,8 and 10 weeks $(\mathrm{P}<0.01)$. BSP expression in the $\mathrm{SCI}$ model group was
\end{abstract}

Correspondence to: Dr Da-An Zhou, Department of Rehabilitation, The Third Affiliated Hospital of Jinzhou Medical University, 2 Heping Road, Linghe, Jinzhou, Liaoning 121000, P.R. China

E-mail: jiangshuilanlan@163.com

Key words: kidney-reinforcing and marrow-beneficial traditional Chinese medicine, spinal cord injury, bone metabolism, bone metabolism related factors significantly higher than that in the normal, sham $+\mathrm{KRMB}$ and normal + KRMB groups at each time point $(\mathrm{P}<0.01)$. BSP expression in SCI model group was higher than that in the SCI + KRMB group at $1(\mathrm{P}<0.05), 2,4,6,8$ and 10 weeks $(\mathrm{P}<0.01)$. In conclusion, KRMB traditional Chinese medicine may have a curative effect on secondary OP resulting from SCI.

\section{Introduction}

Spinal cord injury (SCI) is a catastrophic injury that has a high disability rate and effects feeling, movement and autonomic functions, and has a number of serious secondary life-threatening complications (1). As society develops, the incidence of SCI increases (2). Osteoporosis (OP) is a primary complication of SCI, affecting primarily patients below the level of injury, and increases the probability of fracturing lower limbs (3). The pathological mechanism that causes secondary OP is currently uncertain, and there is, therefore, a lack of systematic and efficient treatment.

According to traditional Chinese medicine theories, the main pathogenesis of OP resulting from SCI is marrow deficiency and kidney asthenia (4,5). Therefore, kidney reinforcing and marrow-beneficial (KRMB) traditional Chinese medicines may be prescribed (6). A number of studies have demonstrated that KRMB can significantly increase bone mineral density (BMD) in rats without ovaries, improve bone tissue, and promote the growth and differentiation of osteoblast (OB) cells (7). In addition, it has been reported that KRMB intervention in rats (weight, $28.125 \mathrm{~g} / \mathrm{kg}$; gavage $1 \mathrm{~h}$ later; $25 \%$ concentration) promotes bone marrow stromal cell proliferation and osteogenic differentiation (8).

The present study aims to investigate the effect of KRMB on kidney and bone marrow metabolism-related factor expression following SCI, and to study the pathomechanism of SCI and OP. This may lay the foundation for the prevention and treatment of OP resulting from SCI using traditional Chinese medicine.

\section{Materials and methods}

Animals. A total of 240 pathogen-free Sprague-Dawley rats (weight, 200 $20 \mathrm{~g} ; 120$ male and 120 female; age, 3 months) 
were obtained from the Experimental Animal Center of Chinese Medical Sciences University (Shenyang, China). Animals were maintained in grouped-housing in a temperature $\left(20-25^{\circ} \mathrm{C}\right)$ and humidity (40-55\%) controlled environment, with a 12 light/dark cycle and ad libitum access to food and water.

Preparation of reagents. KRMB was prepared as a suspension containing $10 \mathrm{~g}$ lyophilized powder of fresh antler (Animal Husbandry of Shunda, Jilin, China), 5 g oyster powder and $15 \mathrm{~g}$ Epimedium brevicornum decoction (both purchased from Jinzhou pharmacy market, Jinzhou, China) and refrigerated at $4^{\circ} \mathrm{C}$.

Drug administration. Rats were allocated at random into the following groups ( $\mathrm{n}=4$ per group): Normal; sham + KRMB; normal + KRMB; SCI + KRMB; and SCI model groups. The KRMB dose was $28.125 \mathrm{~g} / \mathrm{kg}$ body weight (suspension volume, $1 \mathrm{ml}$ ), and the normal group was administered an equivalent volume of saline for 10 weeks, once a day, by gavage. Following the experiments, rats were sacrificed by an anesthetic overdose (10\% chloral hydrate; $300 \mathrm{mg} / \mathrm{kg}$; China Shanghai National Medicine Group Corporation, Shanghai, China).

Surgical procedure. Rats were fasted for $24 \mathrm{~h}$, with free access to water, prior to the operation. Rats were anesthetized with an intraperitoneal injection of $10 \%$ chloral hydrate $(300 \mathrm{mg} / \mathrm{kg})$ and laid in the prone position. The thoracic T9-11 vertebra was marked as the center, and an aseptic operation along the spinous process was performed. A longitudinal incision $(\sim 4 \mathrm{~cm})$ was made, blunt separation stripped the fascia, fat and paravertebral muscle, bite T7-9 spinous process and a laminectomy was performed on the T8 vertebrae in order to fully expose the back and sides of the dural sac. The endorachis and spinal cord were entirely transected using a 10 scalpel (Jinzhou Medical Instruments Factory, Changchun, China), and rat hind limbs convulsed several times prior to flaccid paralysis. Next, a 2-mm incision was made through spinal cord tissues below the T10 spinal segment, and a gelfoam sponge (Jinzhou Medical Instruments Factory) was placed at the broken ends of spinal cord. The endorachis was opened by incision and covered with a fasciai patch, and sutured layer by layer. The sham operation cut off the spinous process and lamina to expose the spinal cord, but there was no resection to the spinal cord (9-11). At 1, 2, 4, 6, 8 and 10 weeks after the surgery, 8 rats were randomly selected from each group and specimens were collected.

Once blood was collected from the rats, eliminated attachment of the muscle fascia, retained periosteum, taken the left hind limb, flushed by the physiological saline and preserved at $-80^{\circ} \mathrm{C}$. BMD expression in the rat distal femur was detected using Lunar Prodigy dual-energy X-ray absorptiometry (GE Healthcare Life Sciences, Chalfont, UK). Post-injury motor behavior is assessed using the Basso, Beattie and Bresnahan (BBB) locomotor scale method (12). Rats are placed on an operating table to observe the hip joint, knee joint, ankle joint, the movement and coordination of walking, the torso and the tail. Rats were analyzed for 4 min between 8 and 9 p.m. following micturition. The average score of the rats' hind legs was then recorded using a single blind method.
Detection of bone gamma-carboxyglutamic-acid containing protein $(B G P)$ expression. Rats were anesthetized with an intraperitoneal injection of $10 \%$ chloral hydrate $(300 \mathrm{mg} / \mathrm{kg})$, blood samples were extracted from the abdominal aortic separation and blood serum was separated by centrifugation for $10 \mathrm{~min}$ at $3,000 \mathrm{x} \mathrm{g}$, and preserved at $-80^{\circ} \mathrm{C}$. BGP expression was detected using an Osteocalcin (BGP) enzyme linked immunosorbent assay (ABE20719; R\&D Systems China Co., Ltd., Shanghai, China) according to the manufacturer's instructions.

Detection of hepcidin mRNA expression. Hepcidin mRNA expression in the liver was determined using an RNA polymerase chain reaction (PCR) kit (AMV) (version 3.0; Takara Biotechnology Co., Inc., Dalian, China) and a 600 bp DNA ladder marker (Beijing TransGen Biotech Co., Ltd., Beijing, China). Primer Premier version 5.0 software (Premier Biosoft International, Palo Alto, CA, USA) was used to design PCR primer sequences for $\beta$-actin and hepcidin, based on the rat $\beta$-actin and hepcidin gene sequences registered in GenBank (http://www.ncbi.nlm.nih.gov/genbank/). Subsequently, $\sim 100 \mathrm{mg}$ fresh rat liver tissue was homogenized in liquid nitrogen. Total RNA (1 $\mu \mathrm{l})$ extraction was performed using TRIzol reagent (Takara Biotechnology Co., Inc.) according to the manufacturer's instructions. A reverse transcription-PCR (RT-PCR) kit (Takara Biotechnology Co., Inc.) was used to synthesize the first strand of cDNA. The reaction conditions were as follows: $42^{\circ} \mathrm{C}$ for $30 \mathrm{~min}, 99^{\circ} \mathrm{C}$ for $5 \mathrm{~min}, 5^{\circ} \mathrm{C}$ for $5 \mathrm{~min}$ followed by preservation at $4^{\circ} \mathrm{C}$. The reaction mixture (total volume, $10 \mu \mathrm{l}$ ) contained $2 \mu \mathrm{l} \mathrm{MgCl}_{2}, 1 \mu \mathrm{l} 10 \mathrm{X}$ RT Buffer, $3.75 \mu \mathrm{l}$ RNase Free $\mathrm{dH}_{2} \mathrm{O}, 1 \mu \mathrm{l}$ dNTP mixture $(10 \mathrm{mM}), 0.25 \mu \mathrm{l}$ RNase inhibitor, $0.5 \mu \mathrm{l}$ AMV Reverse Transcriptase, $0.5 \mu \mathrm{l}$ Oligo dT and $1 \mu \mathrm{l}$ RNA. The hepcidin PCR protocol began with initial denaturation for $5 \mathrm{~min}$ at $94^{\circ} \mathrm{C}$, followed by amplification for $30 \mathrm{sec}$ at $94^{\circ} \mathrm{C}$ for 30 cycles, and $10 \mathrm{~min}$ at $72^{\circ} \mathrm{C}$. The $\beta$-actin PCR protocol began with initial denaturation for $40 \mathrm{sec}$ at $72^{\circ} \mathrm{C}$, followed by an amplification program for $30 \mathrm{~s}$ at $55^{\circ} \mathrm{C}$. PCR products were electrophoresed using a $3-\mu 1$ DNA ladder marker (DL600) with molecular weight standards (100 bp) as the reference. Electrophoresis was performed at $90 \mathrm{~V}$ for $1 \mathrm{~h}$. The primer sequences were as follows: $\beta$-Actin forward, 5'-GGAGATTACTGCCCTGGCTCCTA-3' and reverse, 5'-GACTCATCGTACTCCTGCTTGCTG-3'; and hepcidin forward, 5'-GAAGGCAAGATGGCACTAAGCA-3' and reverse, 5'-TCTCGTCTGTTGCCGGAGATAG-3'. A gel imaging analysis system (Alpha Innotech ChemiImager 5500; BioSurplus, Inc., San Diego, CA, USA) was used to analyze the PCR results.

Determination of bone sialoprotein (BSP). Frozen tibia tissues $(100 \mathrm{mg})$ were lysed in $1 \mathrm{ml}$ ice-cold homogenization radioimmunopreciptation assay buffer (Wuhan Boster Biological Technology, Ltd., Wuhan, Boster) containing a protease inhibitor. The homogenates were centrifuged at 2,580 $\mathrm{x} \mathrm{g}$ for $5 \mathrm{~min}$ at $4^{\circ} \mathrm{C}$ and the supernatant was collected. The protein content was determined using a bicinchoninic acid assay (Beijing Tiandz Biological Technology Co., Ltd.), ensuring that each $20 \mu \mathrm{l}$ contained $50 \mu \mathrm{g}$ protein, and samples were stored at $-20^{\circ} \mathrm{C}$. Each sample (6.08-6.44 $\left.\mu \mathrm{g}\right)$ was separated using $10 \%$ sodium dodecyl sulfonate gel electrophoresis 
Table I. BBB scores ( $\mathrm{n}=8$ per group).

\begin{tabular}{lcccc}
\hline & \multicolumn{4}{c}{ BBB score (days) } \\
\cline { 2 - 5 } Group & 1 & 3 & 5 & 7 \\
\hline Normal & $20.75 \pm 0.460$ & $20.50 \pm 0.53$ & $20.63 \pm 0.520$ & $20.50 \pm 0.530$ \\
Sham + KRMB & $20.63 \pm 0.520$ & $20.75 \pm 0.46$ & $20.50 \pm 0.530$ & $20.38 \pm 0.520$ \\
Normal + KRMB & $20.63 \pm 0.520$ & $20.75 \pm 0.46$ & $20.63 \pm 0.520$ & $20.75 \pm 0.460$ \\
SCI + KRMB & $0.000 \pm 0.000^{\mathrm{a}}$ & $0.375 \pm 0.51^{\mathrm{a}}$ & $0.750 \pm 0.463^{\mathrm{a}}$ & $1.625 \pm 0.744^{\mathrm{a}}$ \\
SCI model & $0.000 \pm 0.000^{\mathrm{a}}$ & $0.250 \pm 0.46^{\mathrm{a}}$ & $0.625 \pm 0.518^{\mathrm{a}}$ & $1.500 \pm 0.756^{\mathrm{a}}$ \\
\hline
\end{tabular}

Data are presented as the mean \pm standard deviation. ${ }^{\text {a }}<0.01$ vs. normal group. $\mathrm{BBB}$, Basso, Beattie and Bresnahan; KRMB, kidney reinforcing and marrow-beneficial medicine; SCI, spinal cord injury.

(60-120 V; 2 h) and transferred to a polyvinylidene difluoride membrane, then semi dry transfer membranes (both purchased from Beijing Solarbio Science and Technology Co., Ltd., Beijing, China) were blocked with $5 \%$ calf serum albumin (Beyotime Biotechnology Co., Ltd., Shanghai, China) at room temperature for $1 \mathrm{~h}$. Following this, the membranes were washed 3 times for $5 \mathrm{~min}$ with Tris-buffered saline with $0.05 \%$ Tween-20 (TBST) (Wuhan Boster Biological Technology, Ltd.). Then, the membranes were incubated overnight at $4^{\circ} \mathrm{C}$ in blotting buffer containing a primary rabbit polyclonal antibody (1:300; BA2329; Wuhan Boster Biological Technology, Ltd.). Membranes were then washed using Tris-buffered saline (Wuhan Boster Biological Technology, Ltd.) and incubated for $1 \mathrm{~h}$ at room temperature in blotting buffer containing poly-horseradish peroxidase-conjugated streptavidin mouse anti-goat IgG antibody (1:3,000; bs-0294Ms; Beijing Biosynthesis Biotechnology Co., Ltd., Beijing, China). Membranes were then washed again with TBST for 5 min and a western blot was performed using 5-bromo-4-chloro-3-indolyl phosphate and p-nitroblue tetrazolium reagent (Beijing Tiandz Biological Technology Co., Ltd.) and $\beta$-actin (42 kD; Beijing Biosynthesis Biotechnology Co., Ltd., Beijing,China) was employed as the internal reference. Membranes were scanned using a Gel Imaging Analyzer (Six One Instrument Factory, Beijing, China), absorbance was measured using a D8 quasi dual beam UV-visible spectrophotometer [Runqee (Shanghai) Instrument Technology Co., Ltd., Shanghai, China] and the absorbance of protein bands was analyzed using gel analysis software (Image J; version 1.47; National Institutes of Health, Bethesda, MA, USA).

Statistical analysis. SPSS software, version 13.0 (SPSS, Inc., Chicago, IL, USA) was used to perform statistical analysis of the experimental data. Data are presented as the mean \pm standard deviation. The electrophoresis results were determined using FluorChem software, version 2.0 (Gene Genus; Syngene, Frederick, MD, USA). $\mathrm{P}<0.05$ was considered to indicate a statistically significant difference.

\section{Results}

$B B B$ score. During the experimental process, a total of 32 rats succumbed to mortality; 18 rats succumbed to mortality in the
SCI model group, and 14 rats succumbed to mortality in the $\mathrm{SCI}+\mathrm{KRMB}$ group, according to the experimental conditions of strict supplements. As presented in Table I, the BBB scores in the SCI and SCI + KRMB groups were significantly reduced in comparison to the normal group $(\mathrm{P}<0.01)$ at 1,3 , 5 and 7 days after the operation. These results suggest that the SCI model was successfully established.

BMD detection. As presented in Table II and Fig. 1, the expression of BMD was not significantly different among the groups at 1 or 2 weeks following the operation. However, BMD levels in the SCI model group were significantly lower than those in the normal group $(\mathrm{P}<0.01)$. Furthermore, BMD levels in the SCI group were significantly lower than that in the $\mathrm{SCI}+\mathrm{KRMB}$ group at $6(\mathrm{P}<0.05), 8$ and 10 weeks $(\mathrm{P}<0.01)$.

Serum BGP expression levels. As presented in Table III, the serum expression levels of BGP in the SCI model group were significantly higher than those in the normal, sham $+\mathrm{KRMB}$ $(\mathrm{P}<0.01)$ and normal + KRMB $(\mathrm{P}<0.05)$ groups at each time point, and significantly lower than the normal + KRMB group $(\mathrm{P}<0.05)$, and the normal and sham $+\mathrm{KRMB}$ group $(\mathrm{P}<0.01)$. The level of serum BGP in the SCI + KRMB group was significantly increased compared with the normal, sham + KRMB and normal + KRMB group at each time point $(\mathrm{P}<0.01)$.

Hepcidin $m R N A$ expression. The primer internal reference gene and target genes of each group were subjected to RT-PCR amplification, which was performed using rat liver tissue. RT-PCR analysis revealed two bands at 200 and 263 bp (Fig. 2). As presented in Table IV, the image analysis software indicated that the expression of hepcidin mRNA in the normal, sham + KRMB and normal + KRMB group was significantly higher than that in the SCI + KRMB and SCI model groups at each time point $(\mathrm{P}<0.01)$. Hepcidin $\mathrm{mRNA}$ expression in the SCI + KRMB group was significantly higher than that in the SCI model group at $1,(\mathrm{P}<0.05), 2,4,6,8$ and 10 weeks $(\mathrm{P}<0.01)$.

BSP expression in rat tibial bone tissue. As presented in Table V and Fig. 3, there are no statistically significant differences in BSP expression among the normal, SCI + KRMB and normal + KRMB groups. However, the BSP expression 
Table II. BMD detection results ( $\mathrm{n}=8$ per group).

$\operatorname{BMD}\left(\mathrm{g} / \mathrm{cm}^{2} ;\right.$ weeks $)$

\begin{tabular}{lcccccc}
\cline { 2 - 6 } Group & 1 & 2 & 4 & 6 & 8 & 10 \\
\hline Normal & $0.210 \pm 0.010$ & $0.209 \pm 0.010$ & $0.211 \pm 0.009^{\mathrm{a}}$ & $0.209 \pm 0.008^{\mathrm{a}}$ & $0.208 \pm 0.009^{\mathrm{a}}$ & $0.209 \pm 0.005^{\mathrm{a}}$ \\
Sham + KRMB & $0.210 \pm 0.010$ & $0.211 \pm 0.011$ & $0.209 \pm 0.009^{\mathrm{a}}$ & $0.211 \pm 0.009^{\mathrm{a}}$ & $0.210 \pm 0.009^{\mathrm{a}}$ & $0.210 \pm 0.013^{\mathrm{a}}$ \\
Normal + KRMB & $0.210 \pm 0.009$ & $0.209 \pm 0.011$ & $0.208 \pm 0.013^{\mathrm{a}}$ & $0.208 \pm 0.012^{\mathrm{a}}$ & $0.210 \pm 0.011^{\mathrm{a}}$ & $0.209 \pm 0.010^{\mathrm{a}}$ \\
SCI + KRMB & $0.210 \pm 0.009$ & $0.203 \pm 0.011$ & $0.196 \pm 0.007$ & $0.190 \pm 0.007^{\mathrm{b}}$ & $0.188 \pm 0.007^{\mathrm{a}}$ & $0.190 \pm 0.006^{\mathrm{a}}$ \\
SCI model & $0.209 \pm 0.012$ & $0.202 \pm 0.011$ & $0.189 \pm 0.010$ & $0.178 \pm 0.009$ & $0.172 \pm 0.010$ & $0.172 \pm 0.009$
\end{tabular}

Data are presented as the mean \pm standard deviation. ${ }^{a} \mathrm{P}<0.01$ and ${ }^{\mathrm{b}} \mathrm{P}<0.05$ vs. SCI model group. BMD, bone mineral density; KRMB, kidney reinforcing and marrow-beneficial medicine; SCI, spinal cord injury.

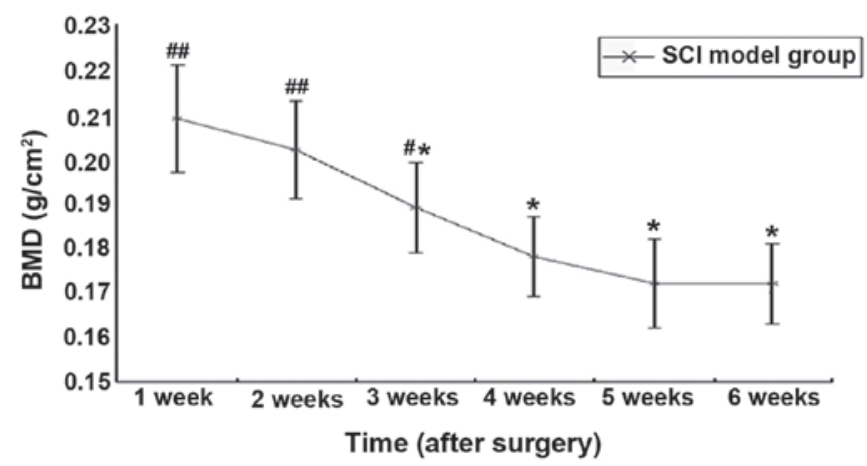

Figure 1. BMD levels following SCI. The BMD values at 2 weeks are significantly different to those at 4,6 and 8 weeks $(\mathrm{P}<0.01)$, and the $\mathrm{BMD}$ value at 6 weeks is lower than that at 4 weeks $(\mathrm{P}<0.05)$. No statistically significant difference was observed between 6,8 and 10 weeks. ${ }^{*} \mathrm{P}<0.05$ vs. 2 weeks after surgery; ${ }^{\#} \mathrm{P}<0.01,{ }^{\# \#} \mathrm{P}<0.05$ vs. 6 weeks after surgery. $\mathrm{BMD}$, bone mineral density; SCI, spinal cord injury.

levels in the SCI + KRMB and SCI model groups were significantly higher compared with the normal, sham + KRMB and normal + KRMB groups at each time point $(\mathrm{P}<0.01)$. In addition, the expression of BSP in the SCI model group was higher than that in the SCI + KRMB group at $1(\mathrm{P}<0.05) 2,4,6,8$ and 10 weeks $(\mathrm{P}<0.01)$.

\section{Discussion}

According to the theory of traditional Chinese medicine, bone ingrowth relies on providing bone marrow with sufficient nutrition $(5,6)$. The main pathogenesis of OP resulting from SCI is marrow deficiency and kidney asthenia, and the mechanism underlying KRMB Chinese medicine in treating OP is a current area of interest (6).

At present, a number of methods exist to establish the SCI model, including the spinal cord transection model that is commonly used in studies as a result of its simple operational procedure and light secondary reaction (13). The present study cut the T10 dura and spinal cord in rats, removed $2 \mathrm{~mm}$ spinal cord tissue from below the T10 spinal segment and filled the gap with gelfoam sponge. The advantage of using this surgical procedure is that it operates at the correct anatomical position and is consistent with the degree of injury. The operation results in motor and sensory function loss below the cross section, causing dysfunction that is attributed to the primary injury of the spinal cord and diminishing the risk of human error (14).

Characteristics of hind limb motor function were assessed in accordance with the BBB scale (15-17). At 1,3, 5 and 7 days following the operation, the BBB scores of the SCI model and SCI + KRMB groups were significantly decreased compared with the normal group $(\mathrm{P}<0.01)$, suggesting that the SCI model was duplicated successfully.

$\mathrm{BMD}$ is a reliable criterion for evaluating the effect of drugs in treating OP, and is an important index to quantify bone mineralization in bone metabolism; therefore, it is regarded as the gold standard criteria for diagnosing OP (18). BMD typically decreases 1 week following SCI, a reduction in bone mass appears at 2 weeks and marked OP appears at 4 weeks, reaching its peak and flattening at 6 weeks (19). In the present study, the BMD levels in the SCI model group were significantly lower compared with the SCI + KRMB group at $6(\mathrm{P}<0.05), 8$ and 10 weeks $(\mathrm{P}<0.01)$. These results indicate that KRMB increases BMD in rats with OP following SCI.

A preliminary study of bone metabolism following SCI demonstrated that osteoclastic resorption performance, with or without slight enhancement of bone formation, is the primary cause of the high-turn-over OP (20), and that an increase in the expression of BGP indicates bone formation (21). In the current study, the expression levels of serum BGP in the SCI model group were significantly higher than those in the normal group $(\mathrm{P}<0.01)$, and that, consistent with the literature (22), this was associated with mild bone formation enhancement following SCI. The measurement of serum BGP is used in evaluating the effect and efficacy of treatments for OP $(23,24)$. Furthermore, the expression levels of serum BGP in the SCI + KRMB group were significantly higher compared with the normal group at each time point $(\mathrm{P}<0.01)$. Therefore, $\mathrm{KRMB}$ may be able to upregulate the expression of serum BGP.

The association between iron metabolism and OP is being increasingly recognized, and both clinical and experimental studies suggest that an iron overload may be a risk factor for OP $(24,25)$. In addition, a previous study has demonstrated that hepcidin expression in OP model groups is significantly different compared with control groups (26). Hepcidin can significantly decrease the apoptosis rate of human fetal OB 1.19 cells and enhance their calcification (27). These 
Table III. BGP levels in rat serum.

\begin{tabular}{|c|c|c|c|c|c|c|}
\hline \multirow[b]{2}{*}{ Group } & \multicolumn{5}{|c|}{ Serum BGP (pg/ml; weeks) } & \multirow[b]{2}{*}{10} \\
\hline & 1 & 2 & 4 & 6 & 8 & \\
\hline Normal & $96.67 \pm 5.90^{\mathrm{a}}$ & $96.74 \pm 7.96^{\mathrm{a}}$ & $96.31 \pm 6.50^{\mathrm{a}}$ & $94.77 \pm 6.35^{\mathrm{a}}$ & $96.13 \pm 6.63^{\mathrm{a}}$ & $97.50 \pm 6.34^{\mathrm{a}}$ \\
\hline Sham + KRMB & $101.20 \pm 5.88^{\mathrm{a}}$ & $99.16 \pm 6.98^{\mathrm{a}}$ & $101.85 \pm 6.25^{\mathrm{a}}$ & $96.49 \pm 5.71^{\mathrm{a}}$ & $97.90 \pm 6.49^{\mathrm{a}}$ & $98.88 \pm 5.47^{\mathrm{a}}$ \\
\hline Normal + KRMB & $97.84 \pm 6.32^{\mathrm{a}}$ & $98.35 \pm 9.05^{\mathrm{a}}$ & $100.83 \pm 6.01^{\mathrm{a}}$ & $96.87 \pm 5.51^{\mathrm{a}}$ & $97.03 \pm 4.55^{\mathrm{a}}$ & $98.51 \pm 6.36^{\mathrm{a}}$ \\
\hline $\mathrm{SCI}+\mathrm{KRMB}$ & $131.93 \pm 7.80^{\mathrm{b}-\mathrm{d}}$ & $138.88 \pm 4.43^{\mathrm{b}-\mathrm{d}}$ & $142.08 \pm 7.16^{\mathrm{b}-\mathrm{d}}$ & $162.50 \pm 7.31^{\mathrm{b}-\mathrm{d}}$ & $160.40 \pm 10.13^{\mathrm{b}-\mathrm{d}}$ & $156.81 \pm 6.90^{\mathrm{b}-\mathrm{d}}$ \\
\hline SCI model & $124.79 \pm 4.81^{\text {b-e }}$ & $123.23 \pm 4.80^{\mathrm{b}-\mathrm{e}}$ & $120.65 \pm 4.60^{\mathrm{b}-\mathrm{e}}$ & $115.76 \pm 5.06^{\mathrm{b}-\mathrm{e}}$ & $112.97 \pm 5.17^{\mathrm{b}-\mathrm{e}}$ & $112.45 \pm 4.70^{\mathrm{b}-\mathrm{e}}$ \\
\hline
\end{tabular}

Data are presented as the mean \pm standard deviation. ${ }^{a} \mathrm{P}<0.01$ vs. $\mathrm{SCI}+\mathrm{KRMB}$ group; ${ }^{\mathrm{b}} \mathrm{P}<0.01$ vs. normal group; ${ }^{\mathrm{c}} \mathrm{P}<0.01 \mathrm{vs}$. sham $+\mathrm{KRMB}$ group; ${ }^{\mathrm{d}} \mathrm{P}<0.05$ vs. normal $+\mathrm{KRMB} ;{ }^{\mathrm{e}} \mathrm{P}<0.05$ vs. $\mathrm{SCI}+\mathrm{KRMB}$ group. BGP, bone gamma-carboxyglutamic-acid; KRMB, kidney reinforcing and marrow-beneficial medicine; SCI, spinal cord injury.

Table IV. Hepcidin mRNA expression in rat liver tissue ( $\mathrm{n}=5$ per group).

\begin{tabular}{llccccc}
\hline & \multicolumn{5}{c}{ Optical density (Hepcidin/ $\beta$-actin; weeks) } \\
\cline { 2 - 7 } Group & \multicolumn{1}{c}{1} & \multicolumn{6}{c}{2} & \multicolumn{1}{c}{6} & \multicolumn{1}{c}{8} & 10 \\
\hline Normal & $0.621 \pm 0.030^{\mathrm{a}, \mathrm{b}}$ & $0.620 \pm 0.031^{\mathrm{a}, \mathrm{b}}$ & $0.620 \pm 0.038^{\mathrm{a}, \mathrm{b}}$ & $0.622 \pm 0.032^{\mathrm{a}, \mathrm{b}}$ & $0.623 \pm 0.039^{\mathrm{a}, \mathrm{b}}$ & $0.618 \pm 0.033^{\mathrm{a}, \mathrm{b}}$ \\
Sham + KRMB & $0.609 \pm 0.018^{\mathrm{a}, \mathrm{b}}$ & $0.608 \pm 0.020^{\mathrm{a}, \mathrm{b}}$ & $0.613 \pm 0.027^{\mathrm{a}, \mathrm{b}}$ & $0.616 \pm 0.029^{\mathrm{a}, \mathrm{b}}$ & $0.621 \pm 0.021^{\mathrm{a}, \mathrm{b}}$ & $0.627 \pm 0.019^{\mathrm{a}, \mathrm{b}}$ \\
Normal + KRMB & $0.614 \pm 0.017^{\mathrm{a}, \mathrm{b}}$ & $0.617 \pm 0.045^{\mathrm{a}, \mathrm{b}}$ & $0.619 \pm 0.039^{\mathrm{a}, \mathrm{b}}$ & $0.622 \pm 0.039^{\mathrm{a}, \mathrm{b}}$ & $0.628 \pm 0.020^{\mathrm{a}, \mathrm{b}}$ & $0.641 \pm 0.011^{\mathrm{a}, \mathrm{b}}$ \\
SCI + KRMB & $0.370 \pm 0.017$ & $0.387 \pm 0.023$ & $0.415 \pm 0.021$ & $0.428 \pm 0.020$ & $0.429 \pm 0.033$ & $0.444 \pm 0.033$ \\
SCI model & $0.341 \pm 0.015^{\mathrm{c}}$ & $0.323 \pm 0.018^{\mathrm{a}}$ & $0.313 \pm 0.016^{\mathrm{a}}$ & $0.300 \pm 0.011^{\mathrm{a}}$ & $0.299 \pm 0.010^{\mathrm{a}}$ & $0.293 \pm 0.018^{\mathrm{a}}$ \\
\hline
\end{tabular}

Data are presented as the mean \pm standard deviation. ${ }^{\mathrm{a}} \mathrm{P}<0.01 \mathrm{vs}$. $\mathrm{SCI}+\mathrm{KRMB}$ group; ${ }^{\mathrm{b}} \mathrm{P}<0.01 \mathrm{vs}$. SCI model; ${ }^{\mathrm{c}} \mathrm{P}<0.05 \mathrm{vs}$. SCI $+\mathrm{KRMB}$. $\mathrm{KRMB}$, kidney reinforcing and marrow-beneficial medicine; SCI, spinal cord injury.

Table V. BSP expression in rat tibial bone tissue ( $\mathrm{n}=5$ per group).

Grey level ratio (BSP/ $\beta$-actin; weeks)

\begin{tabular}{lccclcl}
\cline { 2 - 6 } Group & \multicolumn{1}{c}{1} & \multicolumn{1}{c}{4} & \multicolumn{1}{c}{6} & \multicolumn{1}{c}{8} & \multicolumn{1}{c}{10} \\
\hline Normal & $0.223 \pm 0.017^{\mathrm{a}, \mathrm{b}}$ & $0.227 \pm 0.010^{\mathrm{a}, \mathrm{b}}$ & $0.229 \pm 0.009^{\mathrm{a}, \mathrm{b}}$ & $0.224 \pm 0.012^{\mathrm{a}, \mathrm{b}}$ & $0.231 \pm 0.011^{\mathrm{a}, \mathrm{b}}$ & $0.230 \pm 0.009^{\mathrm{a}, \mathrm{b}}$ \\
Sham + KRMB & $0.229 \pm 0.008^{\mathrm{a}, \mathrm{b}}$ & $0.226 \pm 0.009^{\mathrm{a}, \mathrm{b}}$ & $0.238 \pm 0.011^{\mathrm{a}, \mathrm{b}}$ & $0.228 \pm 0.010^{\mathrm{a}, \mathrm{b}}$ & $0.225 \pm 0.008^{\mathrm{a}, \mathrm{b}}$ & $0.227 \pm 0.013^{\mathrm{a}, \mathrm{b}}$ \\
Normal + KRMB & $0.234 \pm 0.013^{\mathrm{a}, \mathrm{b}}$ & $0.232 \pm 0.010^{\mathrm{a}, \mathrm{b}}$ & $0.228 \pm 0.013^{\mathrm{a}, \mathrm{b}}$ & $0.225 \pm 0.009^{\mathrm{a}, \mathrm{b}}$ & $0.223 \pm 0.007^{\mathrm{a}, \mathrm{b}}$ & $0.223 \pm 0.004^{\mathrm{a}, \mathrm{b}}$ \\
SCI + KRMB & $0.320 \pm 0.014$ & $0.313 \pm 0.008$ & $0.306 \pm 0.014$ & $0.281 \pm 0.012$ & $0.281 \pm 0.016$ & $0.282 \pm 0.009$ \\
SCI model & $0.339 \pm 0.009^{\mathrm{c}}$ & $0.343 \pm 0.013^{\mathrm{a}}$ & $0.372 \pm 0.019^{\mathrm{a}}$ & $0.399 \pm 0.018^{\mathrm{a}}$ & $0.397 \pm 0.015^{\mathrm{a}}$ & $0.388 \pm 0.025^{\mathrm{a}}$ \\
\hline
\end{tabular}

Data are presented as the mean \pm standard deviation. ${ }^{\mathrm{a}} \mathrm{P}<0.01 \mathrm{vs}$. $\mathrm{SCI}+\mathrm{KRMB}$ group; ${ }^{\mathrm{b}} \mathrm{P}<0.01 \mathrm{vs}$. SCI model; ${ }^{\mathrm{C}}<0.05 \mathrm{vs}$. SCI $+\mathrm{KRMB}$. BSP, bone sialoprotein; KRMB, kidney reinforcing and marrow-beneficial medicine; SCI, spinal cord injury.

studies suggest that hepcidin may have a correlation with OB cell metabolism. In the present study, hepcidin expression in the SCI model group was reduced compared with the $\mathrm{SCI}+\mathrm{KRMB}$ group at $1(\mathrm{P}<0.05), 2,4,6,8$ and 10 weeks $(\mathrm{P}<0.01)$. This result suggests that KRMB Chinese medicine is able to increase the expression of hepcidin mRNA in rat livers, which may be involved in the development of OP following SCI.

BSP is the predominant non-collagen material in bone extracellular matrix that participates in cell adhesion, transfer and signal identification associated with the formation of bone tissue and alteration (28). The expression of BSP serves a crucial function in the process of bone absorption (29,30). BSP expression in the SCI model group was significantly higher than that in the normal group at each time point $(\mathrm{P}<0.01)$, and was increased compared with the SCI + KRMB group at $1(\mathrm{P}<0.05), 2,4,6,8$ and 10 weeks $(\mathrm{P}<0.01)$. This suggests that the expression of BSP in the early stage of SCI in rats may be involved in activating the process of bone resorption. Therefore, it may be suggested that KRMB Chinese medicine 
1 week after surgery

A

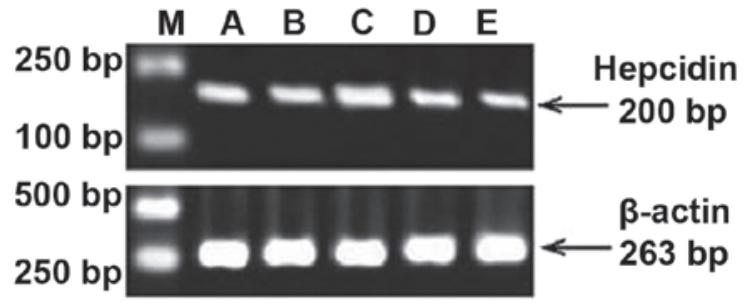

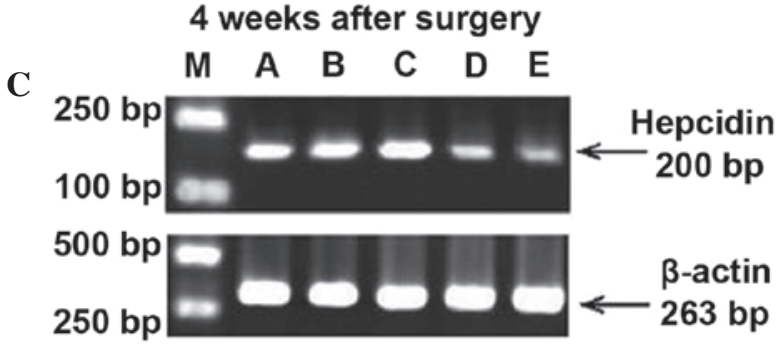

\section{8 weeks after surgery}

E

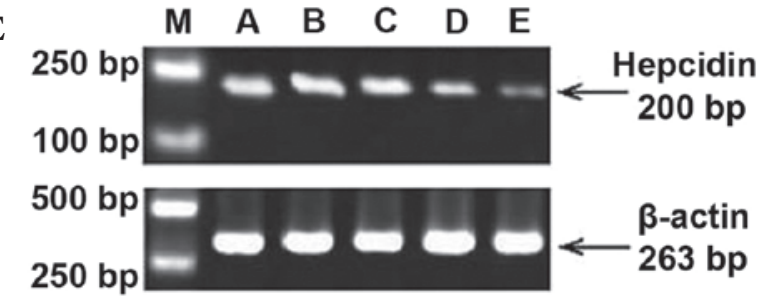

2 weeks after surgery

B

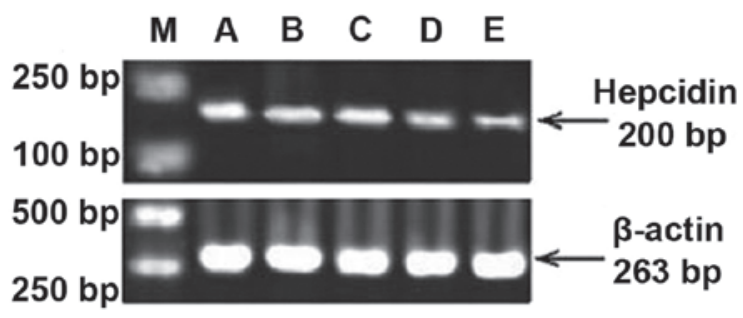

6 weeks after surgery
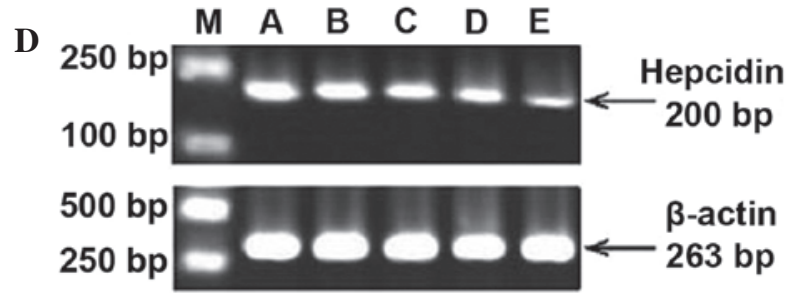

10 weeks after surgery

F

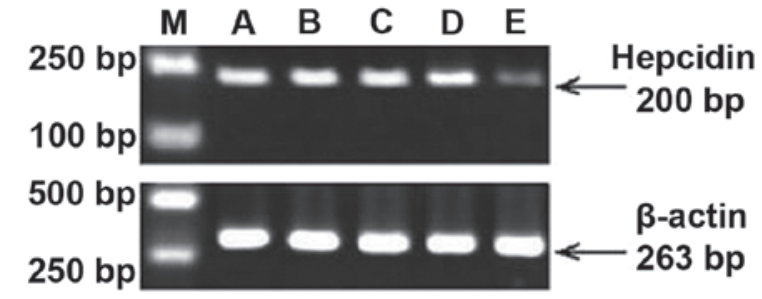

Figure 2. Gel images from reverse transcription polymerase chain reaction amplification of hepcidin mRNA expression at (A) 1, (B) 2 , (C) 4 , (D) 6 , (E) 8 and (F) 10 weeks after operation. m, DNA marker; a, normal group; b, sham operation + KRMB group; c, normal + KRMB group; d, SCI + KRMB group; e, SCI model group. KRMB, kidney reinforcing and marrow-beneficial medicine; SCI, spinal cord injury.

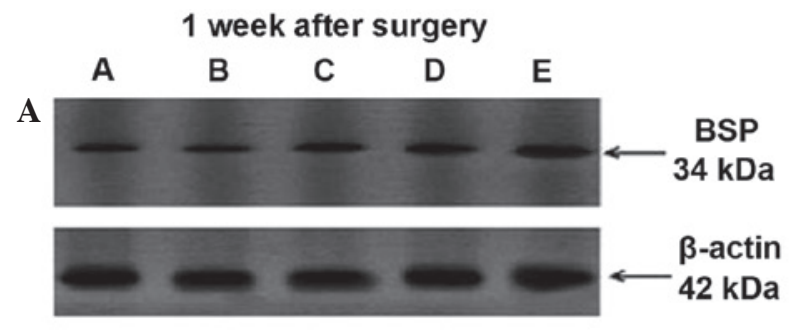

4 weeks after surgery

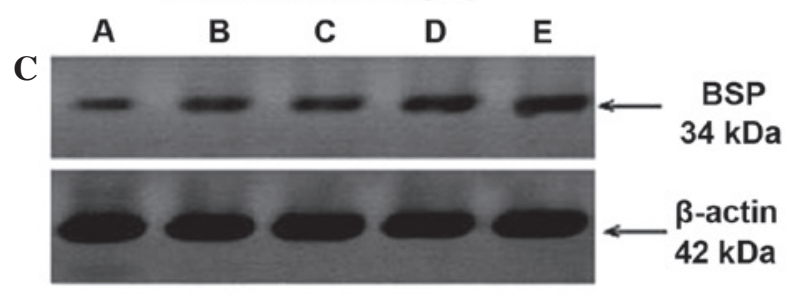

8 weeks after surgery

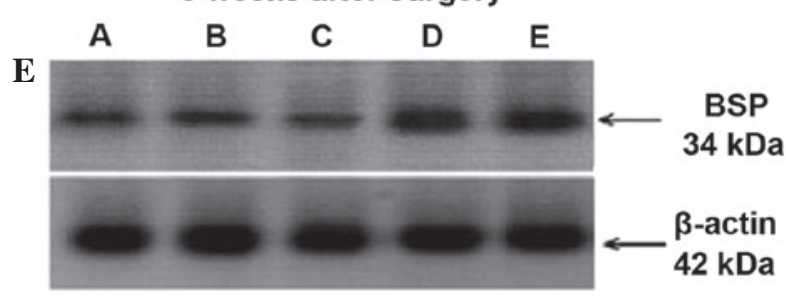

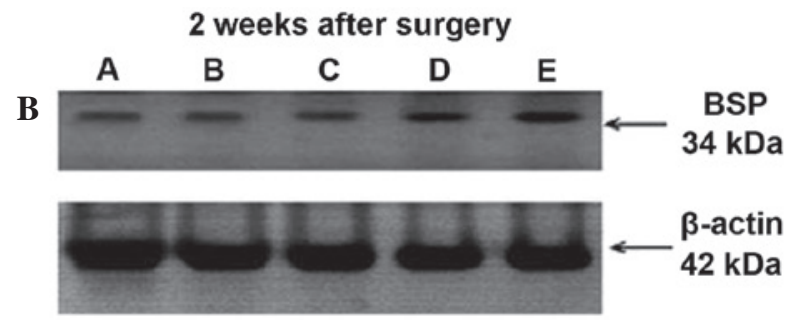

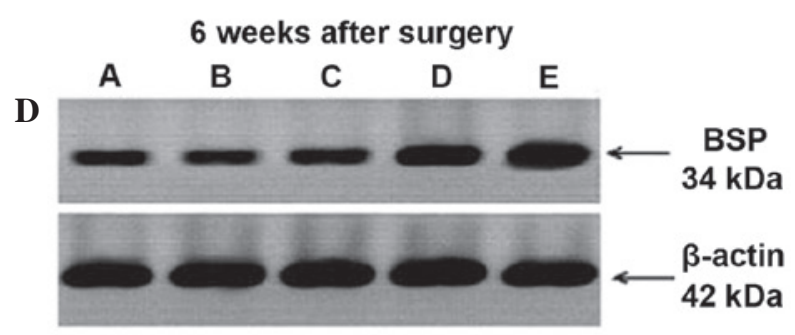

10 weeks after surgery

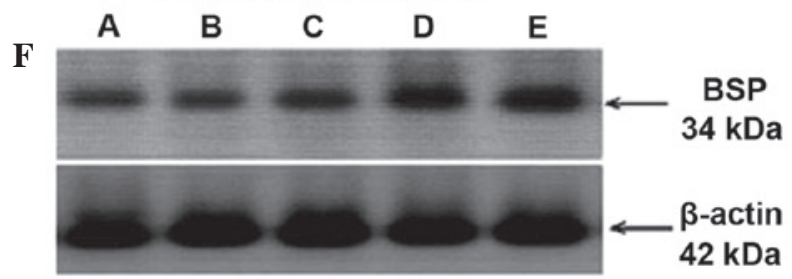

Figure 3. Western blots of BSP expression at (A) 1, (B) 2, (C) 4, (D) 6, (E) 8 and (F) 10 weeks after operation. A, normal group; B, sham operation + KRMB group; C, normal + KRMB group; D, SCI + KRMB group; E, SCI model group. BSP, bone sialoprotein; KRMB, kidney reinforcing and marrow-beneficial medicine; SCI, spinal cord injury. 
delays the progression of OP following SCI by reducing the expression of BSP in tibia bone tissue in rats, resulting in the reduction of bone resorption.

\section{References}

1. Nielson JL, Guandique CF, Liu AW, Burke DA, Lash AT, Moseanko R, Hawbecker S, Strand SC, Zdunowski S, Irvine A, et al: Development of a database for translational spinal cord injury research. J Neurotrauma 31: 1789-1799, 2014.

2. Hamid S and Hayek R: Role of electrical stimulation for rehabilitation and regeneration after spinal cord injury: An overview. Eur Spine J 17: 1256-1269, 2008.

3. Troy KL and Morse LR: Measurement of bone: Diagnosis of SCI-induced osteoporosis and fracture risk prediction. Top Spinal Cord Inj Rehabil 21: 267-274, 2015.

4. Li J, Meng Q, Shan Q, Mao Z, Wang B, Zhang F, Zhao T and Yu P: Extract of Cornus officinalis SIEB ameliorates osteoporosis in spinal cord injured rats. Zhong Guo Gu Zhi Shu Song Za Zhi She 60: 627-633, 2015 (In Chinese).

5. Niu Y and Zheng HX: Effect of herbs with function of reinforcing kidney and replenish marrow on mRNA and protein expression of calcium binding protein - D9K in kidney tissue of rats with glucocorticoid-induced osteoporosis. Ji Lin Zhong Yi Yao 32: 68-69, 2012 (In Chinese).

6. Wang J, Zheng HX, Liu Y,Zhang JP and Liu RH: Effect of reinforcing kidney to replenish marrow herbs compound on mRNA and protein expression of osterix in kidney tissues of rats with glucocorticoid-induced osteoporosis. Guang Ming Zhong Yi Za Zhi 27: 673-677, 2012 (In Chinese).

7. Wang J, Zheng HX, Zong ZH, Yang F, Zhu H and Zhang ZG: Effect of herbs with function of reinforcing kidney and replenish marrow on mRNA and protein expression of Runx 2 in bone tissue of rats with glucocorticoid-induced osteoporosis. Zhong Guo Gu Zhi Shu Song Za Zhi 17: 120-125, 2011 (In Chinese).

8. Zhou DA, Deng YN and Liu L: Effect of kidney-reinforcing and marrow-beneficial traditional Chinese medicine-intervened serum on the proliferation and osteogenic differentiation of bone marrow stromal cells. Exp Ther Med 9: 191-196, 2015.

9. Xie L, Shen YX and Fan ZH: Establishment of rat models of complete spinal cord transection and several relative problems. Ji Zhu Wai Ke Za Zhi 8: 377-380, 2010 (In Chinese).

10. Meng BL, Ba YC, Song SN, Chen SS and Wang TH: Establishment of spinal cord transection injury models in rats. Zhong Guo Zu Zhi Gong Cheng Yan Jiu Yu Lin Chuang Kang Fu 15: 1215-1218, 2011 (In Chinese).

11. Basso DM, Beattie MS and Bresnahan JC: A sensitive and reliable locomotor rating scale for open filed testing in rats. J Neurotrauma 12: 1-21, 1995.

12. Chen M, Kong XY, Ma Q, Zheng X, Zhao S and Zheng XY: Establishment of completely transected spinal cord model and influence of minocycline pretreatment on GFAP expression in rats. Jie Po Xue Za Zhi 37: 352-355, 2014 (In Chinese).

13. Nakae A, Nakai K, Yano K, Hosokawa K, Shibata M and Mashimo T: The animal model of spinal cord injury as an experimental pain model. J Biomed Biotechnol 2011: 939023, 2011.
14. Lim JH, Piedrahita JA, Jackson L, Ghashghaei T and Olby NJ: Development of a model of sacrocaudal spinal cord injury in cloned Yucatan minipigs for cellular transplantation research. Cell Reprogram 12: 689-697, 2010.

15. Yu D, Li M, Ni B, Kong J and Zhang Z: Induction of neuronal mitophagy in acute spinal cord injury in rats. Neurotox Res 24 : $512-522,2013$.

16. Lukovic D, Moreno Manzano V, Stojkovic M, Bhattacharya SS and Erceg S: Concise review: Human pluripotent stem cells in the treatment of spinal cord injury. Stem Cells 30: 1787-1792, 2012.

17. Ward PJ and Hubscher $\mathrm{CH}$ : Persistent polyuria in a rat spinal contusion model. J Neurotrauma 29: 2490-2498, 2012.

18. Rufus P, Mohamed N and Shuid AN: Beneficial effects of traditional Chinese medicine on the treatment of osteoporosis on ovariectomised rat models. Curr Drug Targets 14: 1689-1693, 2013.

19. Ye CQ, Ji SR, Zhang QM, Du LJ and Ren XF: The influence of spinal cord injury on bone metabolism and bone mass density in rats. Zhong Guo Kang Fu Yi Xue Za Zhi 20: 258-260, 2005 (In Chinese).

20. Battaglino RA, Lazzari AA, Garshick E and Morse LR: Spinal cord injury-induced osteoporosis: Pathogenesis and emerging therapies. Curr Osteoporos Rep 10: 278-285, 2012.

21. Lin SJ, Ho HC, Lee YF, Liu NC, Liu S, Li G, Shyr CR and Chang C: Reduced osteoblast activity in the mice lacking TR4 nuclear receptor leads to osteoporosis. Reprod Biol Endocrinol 10: 43, 2012.

22. Liang HD, Yu F, Tong $\mathrm{ZH}$, Zhang HQ and Liang W: Cistanches herba aqueous extract affecting serum BGP and TRAP and bone marrow Smad1 mRNA, Smad5 mRNA, TGF- $\beta 1$ mRNA and TIEG1 mRNA expression levels in osteoporosis disease. Mol Biol Rep 40: 757-763, 2013.

23. Atalay S, Elci A, Kayadibi H, Onder CB and Aka N: Diagnostic utility of osteocalcin, undercarboxylated osteocalcin, and alkaline phosphatase for osteoporosis in premenopausal and postmenopausal women. Ann Lab Med 32: 23-30, 2012.

24. Rossi F, Perrotta S, Bellini G, Luongo L, Tortora C, Siniscalco D, Francese M, Torella M, Nobili B, Di Marzo V and Maione S: Iron overload causes osteoporosis in thalassemia major patients through interaction with transient receptor potential vanilloid type 1 (TRPV1) channels. Haematologia 99: 1876-1884, 2014.

25. Tsay J, Yang Z, Ross FP, Cunningham-Rundles S,Lin H,Coleman R, Mayer-Kuckuk P, Doty SB, Grady RW, Giardina PJ, et al: Bone loss caused by iron overload in a murine model: Importance of oxidative stress. Blood 116: 2582-2589, 2010.

26. Jensen ED, Gopalakrishnan R and Westendorf JJ: Regulation of gene expression in osteoblasts. Biofactors 36: 25-32, 2010.

27. Marie PJ and Kassem M: Osteoblasts in osteoporosis: Past, emerging, and future anabolic targets. Eur J Endocrinol 165: 1-10, 2011.

28. Kruger TE, Miller AH, Godwin AK, Wang J: Bone sialoprotein and osteopontin in bone metastasis of osteotropic cancers. Crit Rev Oncol Hematol 89: 330-341, 2014

29. Yang Y, Mkhonto D, Cui Q and Sahai N: Theoretical study of bone sialoprotein in bone biomineralization. Cells Tissues Organs 194: 182-187, 2011.

30. Uccello M, Malaguarnera G, Vacante M and Motta A: Serum bone sialoprotein levels and bone metastases. J Cancer Res Ther 7: 115-119, 2011. 